\title{
STRATEGI PENINGKATAN INVESTASI NON TAMBANG DI KABUPATEN KUTAI KARTANEGARA
}

\section{(NON-MINE INVESTMENT ENHANCEMENT STRATEGIES IN KUTAI KARTANEGARA DISTRICT)}

\author{
Karmini \\ Jurusan Agribisnis, Fakultas Pertanian, Universitas Mulawarman \\ Jl. Pasir Balengkong, Kampus Gunung Kelua, Kotak Pos 1040, Samarinda, Kalimantan Timur. \\ E-mail: karmini.kasiman@yahoo.com; karmini@faperta.unmul.ac.id
}

Diterima: 13 Maret 2019; Direvisi: 20 Juni 2019; Disetujui: 21 Juni 2019

\begin{abstract}
ABSTRAK
Investasi non tambang berperan dalam perekonomian Kabupaten Kutai Kartanegara. Namun diharapkan peran tersebut meningkat menjadi sama atau lebih besar dibandingkan investasi tambang. Tujuan studi ini adalah untuk mengetahui jenis investasi non tambang, faktor-faktor penentu investasi non tambang, strategi, kebijakan, program, dan kegiatan peningkatan investasi non tambang. Penelitian dilaksanakan di Kecamatan Muara Jawa, Samboja, Sanga-sanga, Anggana, Muara Badak, dan Marang Kayu, Kabupaten Kutai Kartanegara, Provinsi Kalimantan Timur. Data yang dikumpulkan dalam penelitian ini adalah data primer dan sekunder. Terdapat berbagai jenis kegiatan investasi non tambang di Kabupaten Kutai Kartanegara antara lain investasi pada sektor pertanian; industri pengolahan; bangunan; perdagangan, hotel, dan restoran; pengangkutan dan komunikasi; keuangan, persewaan dan jasa perusahaan; jasa; dan lainnya. Faktor-faktor penentu investasi non tambang di lokasi studi adalah potensi sumberdaya alam, potensi sumberdaya manusia, karakteristik wilayah, dan iklim investasi. Hasil penelitian ini menunjukkan berbagai strategi, kebijakan, program, dan kegiatan untuk meningkatkan investasi non tambang di Kabupaten Kutai Kartanegara yang berkaitan dengan pengelolaan sumber daya alam dan sumber daya manusia serta pengembangan wilayah dan iklim investasi.
\end{abstract}

Kata kunci: Investasi, Kutai Kartanegara, non tambang, strategi.

\begin{abstract}
Investment has role in economics of Kutai Kartanegara. However, it is hoped the role will increase become same or more than mining investment. The aims of this study were to know kinds of non-mining investment, factors determine non-mining investment, strategy, regulation, program, and activity to increase non-mining investment. The study was done in Subregency of Muara Jawa, Samboja, Sanga-sanga, Anggana, Muara Badak, and Marang Kayu, Regency of Kutai Kertanegara, Province of East Kalimantan. Data were collected in this study both primary and secondary data. There are various activities of non-mining investments in Regency of Kutai Kartanegara such as investment in sectors of agriculture; manufacturing industries; construction; trade, hotel, and restorant; transportation and communication; financial, leasing, and business service; services, and others. Factors detemine non-mining investment in study areas are potency of natural resources, potency of human resources, charateristics of area, and climate of investment. The results of this study show strategies, regulations, programs, and activities to increase non-mining investment in Regency of Kutai Kartanegara in relation to the management of natural and human resources also the development of region and invesment climate.
\end{abstract}

Keywords: Investment, Kutai Kartanegara, non-mining, strategy.

\section{PENDAHULUAN}

Kabupaten Kutai Kartanegara merupakan salah satu kabupaten di Provinsi Kalimantan Timur yang memiliki potensi sumber daya alam dan manusia yang sangat besar. Luas wilayah kabupaten tersebut meliputi $27.263 \mathrm{~km}^{2}$ dengan jumlah penduduk pada tahun 2006 sebanyak 
542.233 jiwa. Namun, jumlah penduduk tersebut meningkat menjadi 626.680 orang pada tahun 2010. Pada tahun 2014, jumlah penduduk di kabupaten tersebut mencapai 700.439 jiwa dan meningkat 2,48\% menjadi 717.789 jiwa pada tahun 2015 (Badan Pusat Statistik, 2016). Kegiatan pengelolaan potensi daerah dilakukan oleh pelaku usaha melalui investasi pada berbagai sektor perekonomian.

Definisi investasi dalam arti luas adalah mengorbankan rupiah sekarang untuk mendapatkan rupiah di masa depan (Sharpe dkk, 1995). Terdapat 2 (dua) hal utama yang harus diperhatikan dalam berinvestasi yakni waktu dan risiko. Pengorbanan memiliki kepastian dan terjadi saat ini sedangkan hasilnya belum pasti dan baru akan diperoleh kemudian hari. Sementara itu definisi investasi dalam arti sempit merupakan pengeluaran suatu perusahaan untuk membeli barang-barang modal dan perlengkapan produksi dengan tujuan menambah kemampuan produksi barang-barang dan jasa-jasa yang tersedia dalam perekonomian (Sukirno, 2003).

Kegiatan investasi mendorong pertumbuhan ekonomi wilayah karena investasi dilakukan hampir pada seluruh sektor perekonomian. Kontribusi kegiatan investasi terhadap kesejahteraan masyarakat dapat diukur dari besaran Produk Domestik Regional Bruto (PDRB). Minyak dan gas bumi memberikan kontribusi yang besar terhadap pembentukan PDRB Kabupaten Kutai Kartanegara. Selisih antara PDRB dengan dan tanpa minyak dan gas bumi pada tahun 2012, 2013, 2014, dan 2015 adalah sebesar Rp43.595.760,00 juta, Rp43.235.763,00 juta, Rp64.155.245,00 juta, dan Rp45.707.418,00 juta. Kegiatan tambang memberikan kontribusi pada perekonomian daerah Kabupaten Kutai Kartanegara sebesar 32,50\%-40,94\% pada kurun waktu 2012-2015 (data dari Badan Pusat Statistik Kabupaten Kutai Kartanegara (BPS Kukar) (2013-2016) diolah).

Kegiatan tambang masih mendominasi perekonomian Kabupaten Kutai Kartanegara hingga saat ini. Sementara itu setiap sektor ekonomi yang tergolong kegiatan non tambang memiliki peran yang lebih rendah dalam pembentukan PDRB kabupaten tersebut dalam kurun waktu 2012-2015 (hal ini ditunjukkan oleh data PDRB dari BPS Kukar (2013-2016)). Berdasarkan fakta tersebut perlu adanya upaya untuk meningkatkan peran kegiatan non tambang dalam perekonomian masyarakat. Peningkatan peran sektor non tambang dapat dilakukan dengan meningkatkan kuantitas dan kualitas kegiatan ekonomi yang berkaitan erat dengan sektor non tambang di masyarakat. Jika frekuensi dan volume usaha non tambang meningkat maka laju perekonomian diharapkan dapat meningkat lebih cepat.

Langkah awal yang perlu untuk dilakukan untuk mendukung upaya tersebut adalah dengan menyusun strategi peningkatan investasi non tambang. Nasution (1998) menjelaskan bahwa keputusan berinvestasi tergantung pada perbandingan antara harapan tingkat keuntungan (rate of return) investasi tersebut dengan tingkat suku bunga. Jika rate of return lebih besar dari biaya suku bunga atas modal tersebut, maka investor akan melakukan investasi dan sebaliknya.

Tujuan studi ini adalah untuk mengetahui:

1. Jenis-jenis investasi non tambang di Kabupaten Kutai Kartanegara.

2. Faktor-faktor penentu investasi non tambang di Kabupaten Kutai Kartanegara.

3. Strategi dan kebijakan peningkatan investasi non tambang di Kabupaten Kutai Kartanegara.

4. Program dan kegiatan peningkatan investasi non tambang di Kabupaten Kutai Kartanegara.

Hasil penelitian ini diharapkan dapat menjadi bahan masukan bagi pemerintah khususnya pemerintah kabupaten dan berbagai pihak terkait dalam upaya untuk meningkatkan investasi non tambang. 


\section{METODE}

Penelitian dilaksanakan pada bulan Juli hingga Desember 2017. Lokasi penelitian pada 6 kecamatan (Kecamatan Muara Jawa, Samboja, Sanga-sanga, Anggana, Muara Badak, dan Marang Kayu) di Kabupaten Kutai Kartanegara, Provinsi Kalimantan Timur. Data yang dikumpulkan dalam penelitian ini adalah data primer dan sekunder.

Proses pengambilan keputusan strategis selalu berkaitan dengan pengembangan misi, tujuan, strategi, dan kebijakan perusahaan; di mana model analisis situasi yang dapat digunakan adalah analisis Strengths, Weakness, Opportunities, and Threats (SWOT) (Rangkuti, 2002). Analisis data yang dilakukan pada penelitian ini untuk menjabarkan dan menyusun secara sistematis data/informasi yang ada dan dilakukan melalui metode/pendekatan sebagai berikut:

1. Analisis matrik Internal Factor Evaluation (IFE) dan External Factor Evaluation (EFE) untuk mengetahui pengaruh faktor-faktor internal dan eksternal yang mempengaruhi kegiatan investasi non tambang.

2. Analisis SWOT untuk mengidentifikasi posisi daerah melalui evaluasi nilai faktor internal dan eksternal agar dapat memilih strategi peningkatan investasi.

3. Analisis Quantitative Strategic Planning Matrix (QSPM) untuk menetapkan ketertarikan relatif dari strategi-strategi yang telah dipilih dan menentukan strategi mana yang dianggap paling baik untuk diimplementasikan.

4. Analisis secara parsial dan terintegrasi untuk menyusun strategi, kebijakan, program, dan kegiatan untuk peningkatan daya tarik investasi non tambang.

\section{HASIL DAN PEMBAHASAN}

PDRB Kabupaten Kutai Kartanegara tahun 2013 dengan minyak dan gas bumi atas dasar harga berlaku sebesar Rp133.002.682,00 juta. Jika dibandingkan dengan PDRB tahun 2012 (Rp133.944.716,00 juta), terjadi penurunan sebesar Rp942.034,00 juta atau 0,70\%. Sementara itu PDRB dengan minyak dan gas bumi pada tahun 2014 dan 2015 berturut-turut adalah Rp156.702.870,00 juta dan 128.531.932,00 juta. PDRB Kabupaten Kutai Kartanegara tahun 2012, 2013, 2014, dan 2015 tanpa minyak dan gas bumi atas dasar harga berlaku berturutturut sebesar Rp90.348.956,00 juta, Rp89.766.919,00 juta, Rp92.547.625,00 juta, dan Rp82.824.514,00 juta. Berdasarkan data yang ditunjukkan oleh Gambar 1, dapat diketahui bahwa minyak dan gas bumi memberikan kontribusi yang besar terhadap pembentukan PDRB Kabupaten Kutai Kartanegara. Selisih antara PDRB dengan dan tanpa minyak dan gas bumi pada tahun 2012, 2013, 2014, dan 2015 adalah sebesar 32,55\%, 32,51\%, 40,94\%, dan 35,56\% (BPS Kukar, 2013-2016).

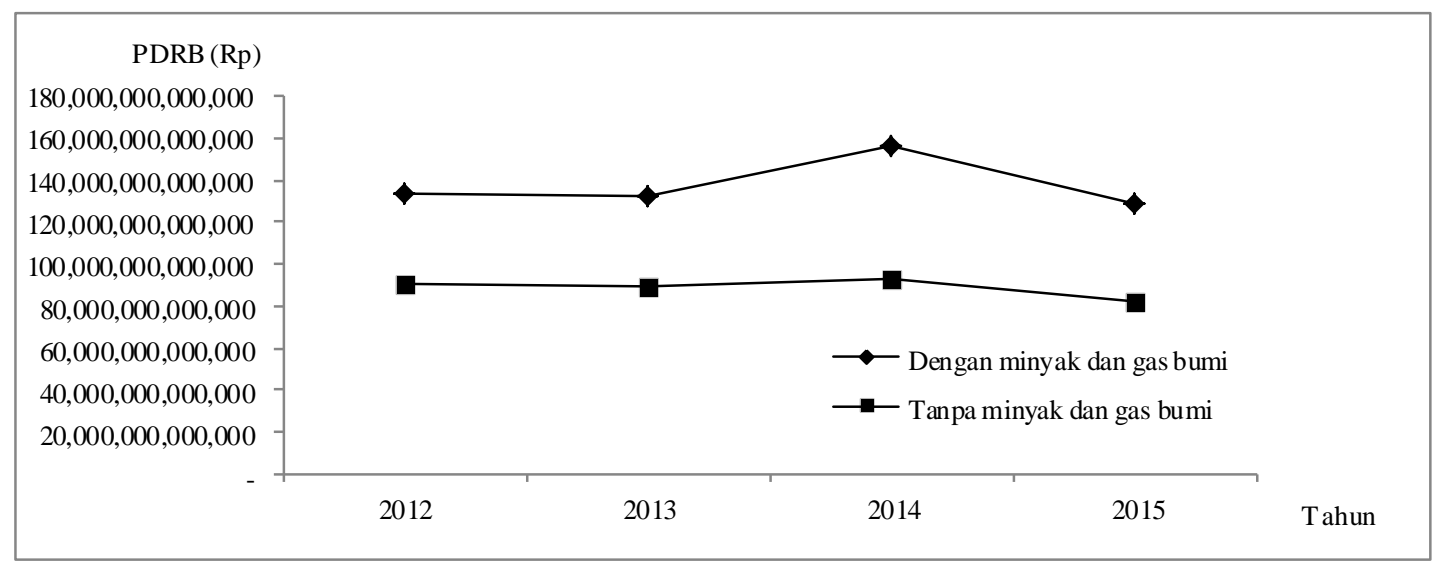

Gambar 1. Produk Domestik Regional Bruto Kabupaten Kutai Kartanegara atas dasar harga berlaku tahun 20122015.

Sumber: BPS Kukar (2013-2016). 
Kegiatan investasi non tambang di Kabupaten Kutai Kartanegara meliputi berbagai jenis antara lain:

1. Investasi pada sektor pertanian dilakukan pada usaha di bidang:

a. Budidaya tanaman pangan (padi dan palawija).

b. Budidaya tanaman hortikultura meliputi sayur-sayuran, buah-buahan, dan tanaman hias.

c. Budidaya tanaman perkebunan.

d. Pemanfaatan hasil hutan kayu dan non kayu.

e. Budidaya peternakan antara lain ternak sapi, kerbau, kambing, babi, unggas, dan lainlain.

f. Budidaya perikanan.

2. Investasi pada sektor industri pengolahan meliputi pengembangan industri mikro, kecil, menengah, dan besar.

3. Investasi pada sektor bangunan.

4. Investasi pada sektor perdagangan, hotel, dan restoran.

5. Investasi pada sektor pengangkutan dan komunikasi.

6. Investasi pada sektor keuangan, persewaan, dan jasa perusahaan.

7. Investasi pada sektor jasa.

8. Investasi pada sektor lainnya.

Berdasarkan hasil analisis SWOT terhadap faktor internal menunjukkan nilai skor kekuatan sebesar 2,29 poin dan nilai skor kelemahan sebesar 2,02 poin atau terdapat selisih 0,27 poin (Tabel 1). Selisih antara nilai skor kekuatan dan kelemahan tersebut memiliki nilai positif. Hal tersebut berarti jika ditinjau dari faktor internal maka Kabupaten Kutai Kartanegara memiliki lebih banyak kekuatan untuk menarik investasi non tambang dibandingkan faktor kelemahan. Sementara itu hasil analisis SWOT terhadap faktor eksternal menunjukkan nilai skor peluang sebesar 1,96 poin dan nilai skor ancaman sebesar 2,36 poin atau terdapat selisih $-0,40$ poin. Selisih antara nilai skor peluang dan ancaman tersebut memiliki nilai negatif. Hal tersebut berarti jika ditinjau dari faktor eksternal maka Kabupaten Kutai Kartanegara memiliki lebih banyak ancaman untuk menarik investasi non tambang dibandingkan faktor peluang.

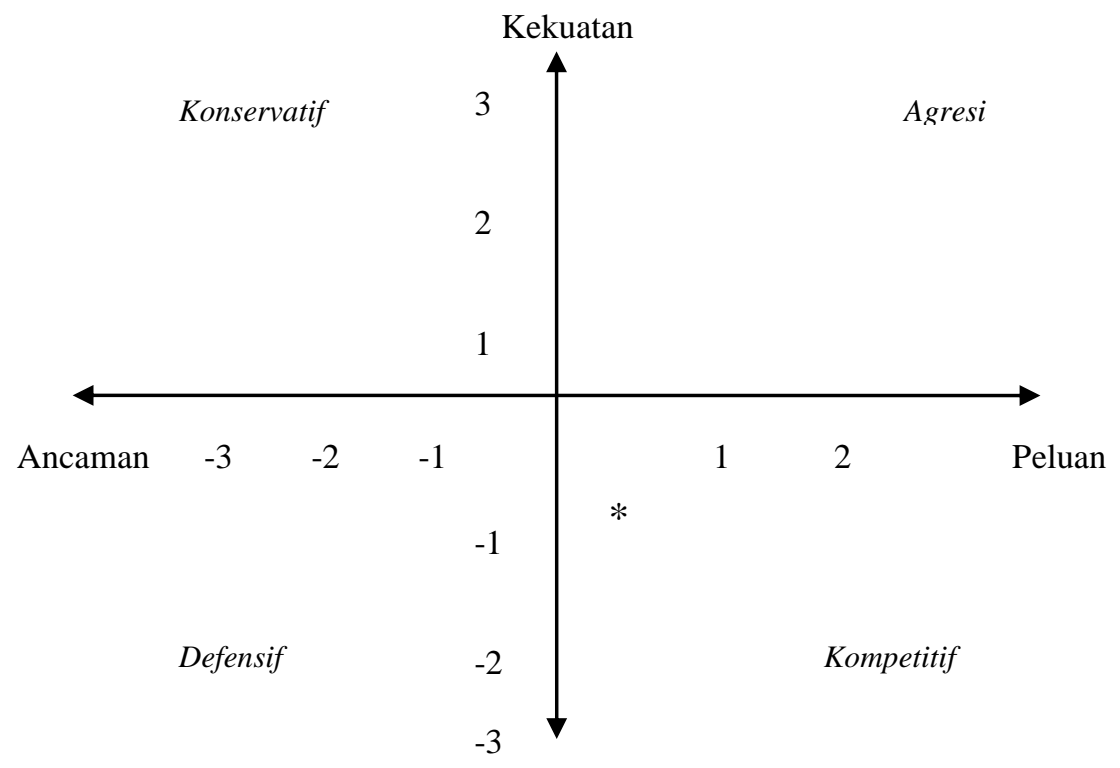

Kelemahan

Gambar 1. Matriks space.

Sumber: Data primer (2017) 
Tabel 1. Hasil analisis SWOT investasi non tambang di Kabupaten Kutai Kartanegara

\begin{tabular}{|c|c|c|c|c|c|c|}
\hline No. & Kategori & Indikator & $\begin{array}{l}\text { Rating } \\
\text { Tinggi }\end{array}$ & $\begin{array}{l}\text { Rating } \\
\text { Rendah }\end{array}$ & Bobot & Skor \\
\hline & Faktor Internal: & Kekuatan & & & & \\
\hline 1 & Potensi sumberdaya alam & Kuantitas sumberdaya alam & 2,89 & 1,11 & 0,20 & 0,58 \\
\hline 2 & Potensi sumberdaya alam & $\begin{array}{l}\text { Sumberdaya alam yang dikelola } \\
\text { pemerintah }\end{array}$ & 1,33 & 2,67 & 0,10 & 0,13 \\
\hline 3 & $\begin{array}{l}\text { Potensi sumberdaya } \\
\text { manusia }\end{array}$ & Kuantitas sumberdaya manusia & 1,11 & 2,89 & 0,20 & 0,22 \\
\hline 4 & Karakteristik wilayah & Keberadaan sarana transportasi. & 3,11 & 0,89 & 0,10 & 0,31 \\
\hline 5 & Karakteristik wilayah & Keberadaan pelabuhan. & 3,11 & 0,89 & 0,10 & 0,31 \\
\hline 6 & Karakteristik wilayah & Keberadaan pasar. & 2,22 & 1,78 & 0,10 & 0,22 \\
\hline 7 & Iklim investasi & Perijinan. & 2,89 & 1,11 & 0,10 & 0,29 \\
\hline \multirow[t]{3}{*}{8} & Iklim investasi & Kebijakan pengelolaan sumberdaya. & 2,22 & 1,78 & 0,10 & 0,22 \\
\hline & & Jumlah & & & 1,00 & 2,29 \\
\hline & Faktor Internal: & Kelemahan & & & & \\
\hline 1 & Potensi sumberdaya alam & $\begin{array}{l}\text { Kemampuan pengelolaan } \\
\text { sumberdaya alam. }\end{array}$ & 1,56 & 2,44 & 0,10 & 0,24 \\
\hline 2 & Potensi sumberdaya alam & $\begin{array}{l}\text { Ketergantungan masyarakat } \\
\text { terhadap sumberdaya alam. }\end{array}$ & 0,89 & 3,11 & 0,10 & 0,31 \\
\hline 3 & $\begin{array}{l}\text { Potensi sumberdaya } \\
\text { manusia }\end{array}$ & Kualitas sumberdaya manusia. & 1,33 & 2,67 & 0,20 & 0,53 \\
\hline 4 & $\begin{array}{l}\text { Potensi sumberdaya } \\
\text { manusia }\end{array}$ & $\begin{array}{l}\text { Kemampuan masyarakat dalam } \\
\text { mengelola sumberdaya alam. }\end{array}$ & 2,22 & 1,78 & 0,10 & 0,18 \\
\hline 5 & Karakteristik wilayah & Jarak tempuh ke ibukota kecamatan. & 3,11 & 0,89 & 0,10 & 0,09 \\
\hline 6 & Karakteristik wilayah & $\begin{array}{l}\text { Waktu tempuh ke ibukota } \\
\text { kecamatan. }\end{array}$ & 3,11 & 0,89 & 0,10 & 0,09 \\
\hline 7 & Karakteristik wilayah & Aksesibilitas antar desa. & 0,89 & 3,11 & 0,10 & 0,31 \\
\hline 8 & Iklim investasi & Sumberdaya milik umum. & 2,67 & 1,33 & 0,10 & 0,13 \\
\hline \multirow[t]{4}{*}{9} & Iklim investasi & Keberadaan hukum adat. & 2,67 & 1,33 & 0,10 & 0,13 \\
\hline & & Jumlah & & & 1,00 & 2,02 \\
\hline & & Selisih (Kekuatan-Kelemahan) & & & & 0,27 \\
\hline & Faktor Eksternal: & Peluang & & & & \\
\hline 1 & Potensi sumberdaya alam & Sumberdaya yang belum dikelola. & 2,22 & 1,78 & 0,20 & 0,44 \\
\hline 2 & Potensi sumberdaya alam & $\begin{array}{l}\text { Tujuan pengelolaan sumberdaya } \\
\text { alam. }\end{array}$ & 1,33 & 2,67 & 0,10 & 0,13 \\
\hline 3 & Potensi sumberdaya alam & $\begin{array}{l}\text { Perpindahan kepemilikan } \\
\text { sumberdaya alam. }\end{array}$ & 2,22 & 1,78 & 0,10 & 0,22 \\
\hline 4 & $\begin{array}{l}\text { Potensi sumberdaya } \\
\text { manusia }\end{array}$ & Peluang usaha. & 2,22 & 1,78 & 0,10 & 0,22 \\
\hline 5 & Karakteristik wilayah & Jenis sarana transfortasi. & 2,00 & 2,00 & 0,20 & 0,40 \\
\hline 6 & Iklim investasi & Kepemilikan sumberdaya. & 1,33 & 2,67 & 0,20 & 0,27 \\
\hline \multirow[t]{3}{*}{7} & Iklim investasi & Keterbukaan masyarakat. & 2,67 & 1,33 & 0,10 & 0,27 \\
\hline & & Jumlah & & & 1,00 & 1,96 \\
\hline & Faktor Eksternal: & Ancaman & & & & \\
\hline 1 & Potensi sumberdaya alam & Kepemilikan sumberdaya alam. & 1,33 & 2,67 & 0,20 & 0,53 \\
\hline 2 & Potensi sumberdaya alam & Pengelola sumberdaya alam. & 1,33 & 2,67 & 0,20 & 0,53 \\
\hline 3 & $\begin{array}{l}\text { Potensi sumberdaya } \\
\text { manusia }\end{array}$ & Tenaga kerja dari luar daerah. & 1,11 & 2,89 & 0,20 & 0,58 \\
\hline 4 & Karakteristik wilayah & Kondisi sarana transportasi. & 2,00 & 2,00 & 0,20 & 0,40 \\
\hline 5 & Iklim investasi & Konfilik sosial/keamanan. & 2,44 & 1,56 & 0,10 & 0,16 \\
\hline \multirow[t]{3}{*}{6} & Iklim investasi & Kewajiban sosial investor. & 2,44 & 1,56 & 0,10 & 0,16 \\
\hline & & Jumlah & & & 1,00 & 2,36 \\
\hline & & Selisih (Peluang-Ancaman) & & & & $-0,40$ \\
\hline
\end{tabular}

Sumber: Data primer (2017). 
Strategi untuk meningkatkan investasi non tambang di Kabupaten Kutai Kartanegara dan kebijakan yang mendukungnya adalah:

1. Peningkatan kemampuan pengelolaan sumber daya alam.

Strategi ini ditempuh agar sumberdaya alam yang belum dikelola dapat dimanfaatkan sebesar-besarnya demi kesejahteraan masyarakat. Sumberdaya alam dapat bermanfaat secara maksimal jika dikelola dengan efektif dan efisien. Oleh sebab itu kemampuan masyarakat dalam mengelola sumberdaya alam dalam kegiatan investasi non tambang harus ditingkatkan. Langkah-langkah kebijakan yang ditempuh adalah peningkatan kemampuan produksi, manajerial, dan pemasaran bagi wirausahawan dan calon wirausahawan dan peningkatan keterampilan tenaga kerja dan calon tenaga kerja.

2. Perubahan bentuk ketergantungan masyarakat terhadap sumber daya alam.

Strategi ini didasarkan atas kenyataan bahwa pada saat ini masyarakat cenderung untuk memanfaatkan sumberdaya alam yang ada disekitarnya dalam bentuk produksi produk primer. Kegiatan tersebut menyebabkan masyarakat sangat tergantung dengan keberadaan sumberdaya alam. Sebagai contoh kegiatan eksploitasi hutan pada umumnya hanya menghasilkan kayu yang memiliki nilai jual lebih rendah jika dibandingkan meubel yang diproduksi dari kayu. Kegiatan pertanian pada umumnya hanya menghasilkan produk seperti pangan dan buah-buahan yang memiliki risiko pemasaran sangat tinggi. Oleh sebab itu perlu ada perubahan bentuk ketergantungan masyarakat terhadap sumberdaya alam agar investor tertarik untuk menanamkan modalnya di Kabupaten Kutai Kartanegara untuk kegiatan produksi produk sekunder dan turunannya. Langkah kebijakan yang dapat ditempuh adalah penyediaan dan penyebaran informasi peluang investasi non tambang.

3. Peningkatan kualitas sumber daya manusia.

Strategi ini dibutuhkan agar kualitas sumberdaya manusia yang ada meningkat sehingga mampu didayagunakan dalam kegiatan investasi pada berbagai sektor ekonomi. Sumberdaya manusia yang berkualitas pada tingkat lokal akan meningkatkan minat investor untuk melakukan investasi. Langkah kebijakan yang dapat ditempuh adalah penyediaan sarana dan prasarana pendidikan dan keterampilan untuk masyarakat. Selain itu perlu dilakukan peningkatan akses untuk memperoleh pendidikan dan keterampilan bagi masyarakat.

4. Peningkatan aksesibilitas antar kampung.

Strategi ini ditempuh agar aksesibilitas antar kampung dapat lebih mudah. Strategi ini perlu didukung upaya untuk meningkatkan ketersediaan sarana dan prasarana perhubungan/transportasi. Langkah kebijakan yang dapat ditempuh adalah peningkatan ketersediaan dan pemeliharaan sarana dan prasarana perhubungan.

5. Pergeseran tujuan pengelolaan sumber daya alam.

Strategi ini ditempuh agar perekonomian masyarakat lokal dapat meningkat intensitasnya. Kegiatan investasi hendaknya sudah menjadi kebutuhan dan membudaya di masyarakat. Langkah-langkah kebijakan yang ditempuh adalah membudayakan kegiatan investasi di kalangan masyarakat dan membuka lapangan kerja untuk masyarakat.

6. Peningkatan kemampuan masyarakat dalam kepemilikan sumber daya alam.

Strategi ini ditempuh agar masyarakat luas memiliki kemampuan kepemilikan sumberdaya alam. Jumlah sumberdaya alam yang dimiliki menunjukkan seberapa besar tingkat kemampuan ekonomi masyarakat. Langkah-langkah kebijakan yang ditempuh adalah peningkatan akses terhadap modal usaha.

Program peningkatan investasi non tambang antara berupa program peningkatan kemampuan produksi, manajerial, dan pemasaran bagi wirausahawan dan calon wirausahawan. Alternatif kegiatan-kegiatan pokok yang dapat dilakukan adalah: 
1. Pelatihan wirausaha bagi pelaku dan calon pelaku investasi.

2. Peningkatan kemampuan manajerial bagi pelaku investasi melalui program magang, pelatihan, studi banding, dan lain-lain.

3. Pengembangan program pelatihan wirausaha yang sesuai dengan potensi ekonomi lokal.

4. Pendampingan usaha.

5. Mendorong tumbuhkembangnya hubungan kemitraan antara pelaku usaha dengan pelaku usaha lain, pemasok, dan konsumen.

6. Penyediaan dan pembangunan sarana dan prasarana pemasaran produk yang dihasilkan oleh pelaku investasi.

Program peningkatan keterampilan tenaga kerja dan calon tenaga kerja dapat dilakukan dengan beberapa kegiatan antara lain:

1. Memfasilitasi pendidikan umum dan kejuruan bagi tenaga kerja dan calon tenaga kerja serta bagi instruktur dan penyuluh.

2. Pengembangan model pendidikan dan pelatihan bagi calon pelaku investasi.

Upaya untuk menarik investor dapat dilakukan dengan program penyediaan dan penyebaran informasi peluang investasi. Kegiatan-kegiatan yang mendukung program kerja tersebut adalah inventarisasi peluang investasi yang terdapat pada setiap kecamatan dan sosialisasi peluang investasi yang memiliki prospek baik untuk dikembangkan oleh masyarakat.

Program kerja untuk penyediaan sarana dan prasarana pendidikan untuk masyarakat perlu diadakan agar kualitas sumberdaya manusia meningkat. Beberapa kegiatan pokok yang dapat dilakukan untuk mendukung program kerja tersebut adalah pembangunan dan pemeliharaan sarana dan prasarana pendidikan. Tidak hanya sarana dan prasarana fisik yang perlu diwujudkan, akan tetapi juga sarana non fisik perlu ditingkatkan ketersediaannya seperti program pendidikan dan pelatihan serta tenaga pendukungnya seperti instruktur dan penyuluh. Oleh karena itu diperlukan program peningkatan akses untuk memperoleh pendidikan dan keterampilan bagi masyarakat. Kegiatan pokok yang dilakukan antara lain peningkatan dana pendidikan dan pelatihan dan peningkatan kesempatan untuk memperoleh pendidikan bagi seluruh kalangan masyarakat.

Peningkatan mobilitas orang dan barang antar wilayah akan mendorong pertumbuhan dan pengembangan pasar. Oleh karena itu perlu upaya untuk meningkatkan akses antar wilayah. Hal itu perlu didukung dengan program peningkatan ketersediaan dan pemeliharaan sarana dan prasarana perhubungan. Kegiatan pokok yang dapat dilakukan antara lain pembangunan dan pemeliharan sarana dan prasarana perhubungan seperti jalan, jembatan, pelabuhan, dan lain-lain.

Pengelolaan sumberdaya alam bertujuan untuk meningkatkan perekonomian masyarakat. Kegiatan pengelolaan sumberdaya diharapkan tidak hanya bertujuan untuk ekstraksi sumberdaya tapi juga memiliki muatan rehabilitasi dan konservasi sehingga kegiatan pengelolaan sumberdaya dapat lestari. Strategi yang dapat dilakukan untuk menggeser tujuan pengelolaan sumber daya dari hanya ekstraksi menjadi mengolah sumberdaya menjadi produk sekunder dan turunannya dapat dilakukan dengan program pembudayaan kegiatan investasi di kalangan masyarakat. Kegiatan pokok yang dapat dilakukan antara lain:

1. Studi untuk mengidentifikasi dan inventarisasi potensi sumberdaya alam di tingkat lokal.

2. Sosialisasi peluang pemanfaatan sumberdaya lokal untuk kegiatan usaha di bidang non tambang.

3. Pembaharuan sistem perijinan investasi yang mensyaratkan pembagian tugas, wewenang, dan koordinasi yang lebih intensif dari seluruh lembaga terkait.

4. Mendorong pengembangan usaha baru berbasis potensi ekonomi lokal.

5. Pembentukan dan pembinaan sentra-sentra usaha kecil, menengah, dan besar. 
6. Pembangunan, pengembangan, dan pemeliharaan pasar serta perluasan pangsa pasar bagi produk hasil industri.

Program kerja yang lain adalah peningkatan akses investor terhadap modal usaha. Kegiatan pokok yang dapat dilakukan adalah peningkatan dan pengembangan lembaga keuangan dan penetapan suku bunga kredit yang berpihak pada pelaku usaha. Dengan semakin tingginya jumlah lembaga keuangan yang ada di masyarakat maka akan semakin mudah masyarakat memperoleh pelayanan jasa keuangan. Hal ini akan mendorong pertumbuhan ekonomi daerah. Kegiatan lain yang dapat dilakukan adalah pemberian subsidi bagi pelaku usaha berupa modal usaha, sarana produksi, atau prasarana produksi.

\section{KESIMPULAN}

Kesimpulan dari hasil studi ini adalah:

1. Jenis kegiatan investasi non tambang di Kabupaten Kutai Kartanegara meliputi berbagai kegiatan usaha yang bergerak di bidang pertanian dan hortikultura, perkebunan, kehutanan, peternakan, perikanan, perindustrian, bangunan, perdagangan, hotel, restoran, pengangkutan, komunikasi, keuangan, persewaan, jasa perusahaan, jasa, dan lain-lain.

2. Faktor-faktor penentu investasi non tambang di Kabupaten Kutai Kartanegara adalah potensi sumberdaya alam, potensi sumberdaya manusia, karakteristik wilayah (potensi sumberdaya fisik), dan iklim investasi.

\section{REKOMENDASI}

Rekomendasi yang dapat diberikan sehubungan dengan hasil studi adalah:

1. Strategi untuk meningkatkan investasi non tambang di Kabupaten Kutai Kartanegara antara lain:

a. Peningkatan kemampuan pengelolaan sumber daya alam;

b. Perubahan bentuk ketergantungan masyarakat terhadap sumber daya alam;

c. Peningkatan kualitas sumber daya manusia;

d. Peningkatan aksesibilitas antar kampung;

e. Pergeseran tujuan pengelolaan sumber daya alam;

f. Peningkatan kemampuan masyarakat dalam kepemilikan sumber daya alam.

Strategi tersebut didukung berbagai bentuk kebijakan yang relevan.

2. Terdapat 6 program untuk meningkatkan investasi non tambang di Kabupaten Kutai Kartanegara. Program kerja tersebut dijabarkan dalam bentuk 23 kegiatan pokok.

\section{DAFTAR PUSTAKA}

Badan Pusat Statistik Kabupaten Kutai Kartanagara (BPS Kukar). (2013-2016). Kabupaten Kutai Kartanegara dalam Angka Tahun 2013-2016. Tenggarong: BPS Kukar.

Nasution, M. (1998). Ekonomi Moneter. Uang dan Bank. Jakarta: Djambatan.

Rangkuti, F. (2002). Analisis SWOT Teknik Membedah Kasus Bisnis. Reorientasi Konsep Perencanaan Strategis untuk menghadapi Abad 21. Jakarta: Gramedia Pustaka Utama.

Sharpe, W.F., Alexander, G.J., dan Bailey, J.V. (1995). Investasi. Jakarta: Intermasa.

Sukirno, S. (2003). Pengantar Teori Ekonomi Makro. Jakarta: Raja Grafindo Persada. 